\title{
Upaya Guru Dalam Meningkatkan Kualitas Pembelajaran Melalui Penerapan Teknologi Informasi di MI Miftahul Ulum Bago Pasirian
}

\author{
Warda Maghfiroh Husein \\ Program Studi Pendidikan Guru Madrasah Ibtidaiyah, Fakultas Agama Islam, \\ Universitas Nurul Jadid \\ wardamaghfiroh182@gmail.com
}

\begin{abstract}
Abstrak: Upaya peningkatan kualitas pendidikan di Indonesia dilakukan dengan berbagai cara. Salah satunya yaitu dengan mengubah pendidikan konvensional menjadi pendidikan berbasis teknologi. Strategi dalam meningkatkan kualitas pendikan yakni dilakukan dengan menerapkan teknologi informasi dalam pembelajaran di sekolah. Dengan penerapan tersebut akan mendukung proses pembelajaran yang menghasilkan siswa-siswa terampil dalam mengantisipasi kemajuan IPTEK. Tujuan penelitian ini ialah untuk mengetahui bagaimana guru dan penerapan teknologi informasi dalam meningkatkan kualitas pembelajaran. Penelitian yang digunakan ialah pendekatan kualitatif dari hasil observasi, interview dan dokumentasi. Subjek yang dijadikan dalam penelitian ini ialah lembaga MI Miftahul Ulum Bago Pasirian. Berdasarkan penelitian yang dilakukan peneliti, peran yang dilakukan guru dalam pembelajaran yaitu: pertama, mendorong siswa berinteraksi dengan sumber belajar atau media pembelajaran; kedua, mendorong siswa untuk melakukan diskusi dengan teman-temannya; ketiga, mengajukan pertanyaan dari guru kepada siswa atau siswa kepada temannya; keempat, memantau persepsi dan proses berfikir siswa; kelima, memantau dan mengamati hasil pembelajaran tersebut; keenam, sebagai penengah dalam diskusi siswa; dan ketujuh, melakukan evaluasi untuk selalu meningkatkan hasil belajar siswa. Peran tersebut diiringi dengan menerapkan sistem teknologi informasi dalam pembelajaran.
\end{abstract}

Kata kunci: guru; penerapan tekonologi informasi; kualitas pembelajaran

Abstract: Efforts to improve the quality of education in Indonesia are carried out in various ways. One of them is by changing conventional education into technology-based education. The strategy in improving the quality of education is done by applying information technology in learning in schools. With this application, it will support the learning process that produces skilled students in anticipating the progress of science and technology. The purpose of this study was to find out how teachers and the application of information technology in improving the quality of learning. The research used is a qualitative approach from the results of observations, interviews and documentation. The subject used in this study is the MI Miftahul Ulum Bago Pasirian institution. Based on research conducted by researchers, the roles played by teachers in learning are: first, encouraging students to interact with learning resources or learning media; second, encouraging students to have discussions with their friends; third, asking questions from the teacher to students or students to their friends; fourth, monitoring students' perceptions and thinking processes; fifth, monitor and observe the learning outcomes; sixth, as a mediator in student discussions; and seventh, evaluating to always improve student learning outcomes. This role is accompanied by implementing information technology systems in learning.

Keywords : teacher; application of information technology; quality of learning 


\section{Pendahuluan}

Pendidikan merupakan salah satu bidang yang sangat penting bagi manusia dan tidak dapat dipisahkan dengan kehidupan manusia. Hal ini disebabkan pendidikan adalah bagian dari suatu proses yang diharapkan untuk mencapai tujuan serta dapat mendorong kualitas manusia. Salah satu strategi untuk meningkatkan kualitas pendidikan ialah dengan meningkatkan kualitas pembelajaran yang didalamnya peran terpenting adalah seorang guru.

Pekerjaan sebagai guru adalah pekerjaan yang luhur dan mulia, baik ditinjau dari sudut masyarakat dan negara dan ditinjau dari sudut keagamaan. Guru sebagai pendidik adalah seseorang yang berjasa besar terhadap bangsa dan negara. Tinggi atau rendahnya kebudayaan suatu masyarakat tergantung kepada pendidikan dan pengajaran yang diberikan oleh guru. Semakin berkualitas pendidikan guru, maka semakin baik pula mutu pendidikan dan pengajaran yang diterima oleh siswa dan semakin tinggi pula derajat masyarakat (Siswanto, 2013).

Dalam hadits (Hamidy, 1992) disebutkan:

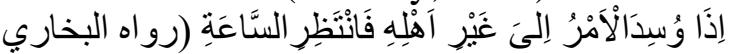

Artinya : "Jika segala sesuatu di berikan kepada yang bukan ahlinya, maka tunggu waktu kehancurannya" (HR. Bukhari).

Berdasarkan hadits di atas, dijelaskan bahwa apabila suatu urusan diberikan kepada bukan ahlinya, maka kehancuran tak akan lama akan datang. Dari konsep hadis tersebut, seorang guru atau pendidik haruslah memiliki pemahaman yang dalam tentang pengajaran. Hal ini dikarenakan jika guru tidak memiliki pemahaman yang dalam tentang pengajaran, maka tujuan pembelajaran tidak akan tercapai dengan baik.

Dalam pendidikan melibatkan proses belajar mengajar antar guru dan siswa. Dalam proses belajar mengajar, teknik penyampaian pesan merupakan bagian penting dari sub-komponen pembelajaran. Hal ini dikarenakan sangat menentukan keberhasilan suatu proses pembelajaran. Sebagaimana disebutkan Undang-Undang Dasar No 20 Tahun 2003 tentang Sistem Pendidikan Nasional yang mengemukakan bahwa penyelenggaraan pendidikan pada esensinya yaitu peningkatan kualitas sumber daya manusia.

Dalam keberhasilan suatu pembelajaran, kualitas siswa tidak pernah lepas dari peran dan usaha guru yang memiliki kompetensi dalam bidangnya. Dalam meningkatkan kualitas pendidikan dalam suatu lembaga diperlukan guru yang benar-benar memiliki kompetensi dalam mengajar, karena pada hakikatnya guru memegang peranan penting dalam perencanaan dan pengembangan kurikulum. Dengan demikian guru yang berkualitas akan melahirkan pendidikan yang berkualitas yang berimplikasi kepada lahirnya generasi yang berkualitas pula sehingga dapat bersaing di era globalisasi ini.

Perkembangan zaman dan teknologi semakin meningkat, sehingga membawa dampak perubahan dalam kehidupan manusia. Melihat kenyataan bahwa teknologi informasi dan komunikasi tidak sekadar sebagai alat pelengkap manusia saja tetapi sudah menjadi bagian dari kehidupan pokok manusia.

The development of information technology that is increasingly rapid in the era of globalization can not be avoided anymore influence on the world of education. Changes in the learning process are needed to make updates in accordance with the dynamics of the increasingly rapid development (Muali et al., 2018). Tuntutan global menuntut dunia pendidikan selalu senantiasa menyesuaikan perkembangan teknologi terhadap usaha peningkatan mutu pendidikan, salah satunya melalui penerapan teknologi informasi dalam pembelajaran guna meningkatkan kualitas siswa. 
Peran TI (Teknologi Informasi) semakin nyata dalam berbagai bidang, bahkan dalam peningkatan keilmuan, dengan penggunaan TI diharapkan dapat mendorong kebangkitan Indonesia dalam era globalisasi (Meningkatkan \& Pendidikan, n.d.). Seiring dengan perkembangan teknologi pendidikan beserta infrastruktur penunjangnya, upaya peningkatan mutu pendidikan antara lain dapat dilakukan melalui pemanfaatan teknologi pendidikan dalam kegiatan pembelajaran (Training et al., 1984). Dengan begitu, banyak bentuk media pembelajaran yang dapat digunakan. Tidak hanya di sekolah, di rumahpun siswa dapat belajar dengan fasilitas yang telah disediakan.

Pemanfaatan teknologi informasi dan komunikasi dalam proses pembelajaran dilakukan dalam rangka meningkatkan efektifitas pelaksanaan proses pembelajaran yang pada akhirnya diharapkan dapat meningkatkan hasil belajar siswa serta mutu individu para peserta didik dalam hal penggunaan teknologi secara lebih tepat dan bermanfaat.

Tercapainya tujuan pendidikan tergantung kepada bagaimana proses pembelajaran berlangsung dan dijalankan secara profesional. Hal ini melibatkan dua orang yang aktif, yaitu guru dan siswa. Guru sebagai pencipta kondisi dalam proses pembelajaran, sedangkan siswa sebagai pihak yang menikmati kondisi pembelajaran yang dilakukan guru. Siswa yang berperan sebagai subjek dalam pembelajaran berperan penting dalam menentukan sukses tidaknya kegiatan belajar.

Untuk mencapai tujuan pendidikan, perubahan dalam dunia pendidikan dituntut untuk melakukan s inovasi dan kreativitas dalam proses pembelajaran (Setiadi et al., 2018). Melihat perkembangan saat ini, dengan hanya menggunakan pembelajaran konvensional (teacher centered) sudah bukan waktunya lagi. Penggunaan sistem teacher centered dianggap kurang efektif karena disini siswa hanyalah mendengarkan apa yang diterangkan oleh gurunya. Berbeda dengan penggunaan pembelajaran student centered yang menuntut siswanya lebih aktif dan mandiri di kelas yang akan memudahkan siswanya memahami pembelajaran.

Sistem Teknologi Informasi dan Komunikasi memberikan jangkauan yang luas, cepat, efektif dan efisien terhadap penyebarluasan informasi ke berbagai penjuru dunia. Teknologi informasi berkembang sejalan dengan perkembangan teori dan komunikasi untuk menunjang proses pembelajaran. Melalui penerapan teknologi informasi kita dapat meningkatkan kualitas SDM. Upaya yang dapat dilakukan berkaitan dengan peningkatan kualitas di sekolah adalah mengembangkan sistem pembelajaran yang berorientasi pada siswa dengan kebutuhan siswa yang menantang, aktif, kreatif dan mandiri serta menyenangkan melalui penerapan teknologi informasi.

Untuk mencapai kualitas dan meningkatkan efisiensi dan efektivitas pembelajaran, kegiatan pembelajaran yang dilakukan perlu menggunakan Teknologi Informasi. Dalam dunia pendidikan, terdapat 4 manfaat TIK, yaitu pertama, sebagai gudang ilmu pengetahuan, yang dapat dimanfaatkan sebagai referensi ilmu pengetahuan terkini, manejemen pengetahuan, jaringan pakar beragam bidang ilmu, jaringan antar instansi pendidikan, pusat pengembangan materi ajar, dan wahana pengembangan kurikulum. Kedua, TIK juga dapat digunakan sebagai alat bantu pembelajaran, yaitu (1) sebagai alat bantu guru yang meliputi animasi peristiwa, alat uji siswa, sumber referensi ajar, evaluasi kinerja siswa, simulasi kasus, alat peraga visual, dan media komunikasi antar guru; (2) sebagai alat bantu interaksi, yang meliputi komunikasi gurusiswa, kolaborasi kelompok studi, dan manejemen kelas terpadu, dan (3) sebagai alat bantu siswa meliputi : buku interaktif, belajar mandiri, latihan soal, media ilustrasi, simulasi pelajaran, alat karya siswa, dan media komunikasi antar siswa. Ketiga, TIK sebagai fasilitas pembelajaran, dimanfaatkan sebagai perpustakaan elektronik, kelas visual, aplikasi multi media, kelas teater 
multimedia, kelas jarak jauh, papan elektronik. Keempat TIK sebagai infra struktur. merupakan dukungan teknis dan aplikasi untuk pembelajaran baik dalam skala menengah maupun luas (Suroko (Akakom, n.d.)).

Berdasarkan observasi di MI Miftahul Ulum Bago Pasirian, yang telah melakukan perubahan sejak tahun 2017 dalam proses pembelajarannya, yaitu menggunakan teknologi informasi mulai kelas 4, kelas 5 dan kelas 6. Penggunaan teknologi informasi tersebut bisa berupa laptop, iphone, ipad, android dan tablet yang harus dimiliki setiap individu yang akan digunakan selama pembelajaran berlangsung.

Penerapan teknologi informasi di MI Miftahul Ulum Bago Pasirian dilaksanakan selama proses pembelajaran baik itu kegiatan rutin setiap hari atau ketika UTS dan UAS. Hal tersebut dapat menjadikan siswa lebih mandiri dan lebih aktif dalam kegiatan pembelajaran serta guru sebagai fasilitator dan mediator. Dengan begitu, peran guru serta penerapan teknologi informasi dapat meningkatkan kualitas pembelajaran. Berdasarkan uraian tersebut, peneliti tertarik untuk melakukan penelitian dengan tujuan untuk mengetahui bagaimana guru dan penerapan teknologi yang dapat meningkatkan kualitas pembelajaran di lembaga MI Miftahul Ulum Bago Pasirian.

\section{Metode Penelitian}

Pendekatan penelitian ini termasuk jenis pendekatan penelitian kualitatif, yakni semua informasi dalam penelitian ini disajikan dalam bentuk kata-kata atau kalimat. Penelitian ini menggunakan analisis deksriptif yaitu menggambarkan fakta atau data yang diperoleh di lapangan.

Metode pengumpulan data yang dilakukan yaitu: pertama, Metode dokumentasi, yaitu metode pengumpulan data berkaitan dengan hal-hal atau variabel dalam penelitian melaui fotofoto dan arsip-arsip kegiatan sekolah yang berkaitan dengan proses pembelajaran teknologi informasi. Kedua, Metode observasi yaitu peneliti mengamati secara langsung proses pembelajaran teknologi informasi. Ketiga, Metode interview, yaitu melakukan wawancara atau tanya jawab dengan pihak terkait.

Setelah semua data dikumpulkan, langkah selanjutnya analisis data yaitu mengolah data menggunakan analisis deskriptif yang kemudian ditarik kesimpulan. Subjek dalam penelitian ini adalah MI Miftahul Ulum yang beralamatkan Desa Bago Kecamatan Pasirian Kabupaten Lumajang. Informan dalam penelitian ini adalah guru dan wali kelas di MI Miftahul Ulum Bago Pasirian.

\section{Hasil dan Pembahasan \\ Guru dan Media Pembelajaran}

Secara umum, orang tidak mengalami kesulitan dalam menjelaskan siapa guru dan sosok guru. Dalam hal ini, makna guru dikaitkan dengan profesi yang terkait dengan dengan pendidikan anak di lembaga pendidikan formal. Semua orang yakin bahwa guru memiliki andil yang sangat besar terhadap keberhasilan pembelajaran di sekolah.

Keberadaan guru merupakan faktor yang sangat penting dalam proses pengajaran di sekolah. Hal itu disebabkan guru merupakan faktor yang menunjang pencapaian keberhasilan di sekolah. Seorang guru haruslah memiliki kompetensi yang baik. Mengajar bukanlah suatu hal yang mudah melainkan suatu kegiatan yang penuh permasalahan (Hamzah, 2017). Oleh sebab itu, sangatlah penting seorang guru memahami hal-hal yang berkaitan dengan pengajaran.

Guru merupakan aktor utama terjadinya perubahan pada masyarakat. Guru juga merupakan kreator kader-kader masa depan bangsa yang nantinya akan memberi warna pada peradaban 
manusia. Oleh karena itu, profesionalisme sangatlah penting bagi guru guna menunjang keberhasilan pembelajaran di sekolah. Hal ini harus didukung oleh wawasan, skill, moral kapasitas dan integritas keilmuannya. Dengan begitu, keberhasilan pembelajaran akan mempengaruhi peningkatan kualitas siswa.

Media pembelajaran merupakan salah satu penyalur pesan antara guru dan siswa. Media pembelajaran adalah alat, metode, dan teknik yang digunakan dalam rangka lebih mengefektifkan komunikasi dan interaksi antara guru dan siswa dalam proses pendidikan dan pengajaran di sekolah (Khasanah \& Pratiwi, 2018). Media pembelajaran dihadirkan dengan harapan agar pembelajaran dapat terarah dan dapat mencapai tujuan pembelajarannya.

Dalam pembelajaran, media memegang peranan penting dalam mencapai sebuah tujuan belajar. Hubungan komunikasi antara guru dan peserta didik akan lebih baik dan efisien jika menggunakan media. Media dalam proses belajar mengajar memiliki dua peranan penting (Rustam, 2011), yaitu: pertama, Media sebagai alat bantu mengajar atau sebagai dependent media karena posisi media disini sebagai alat bantu (efektivitas). Kedua, Media sebagai sumber belajar yang digunakan sendiri oleh peserta didik secara mandiri atau independen media. Independent media dirancang secara sistematis agar dapat menyalurkan informasi secara terarah untuk mencapai tujuan yang telah ditentukan.

Jadi, penggunaan media dalam pembelajaran merupakan sarana penyampaian pesan antar guru dan siswa, sehingga informasi yang ingin disampaikan oleh guru lebih mudah dipahami oleh siswa. Terdapat banyak macam media yang dapat digunakan guru dalam kegiatan pembelajaran, seperti alat peraga, LCD/Proyektor dan lain-lain.

Perkembangan teknologi yang semakin canggih dapat membantu pekerjaan manusia dengan mudah. Begitupun dengan pendidikan, dengan perkembangan teknologi sudah seharusnya dunia pendidikan melakukan pembaharuan dalam proses pembelajaran guna meningkatkan mutu siswa. Penggunaan teknologi informasi dapat dijadikan sebagai media untuk menunjang keberhasilan siswa dalam proses pembelajaran yang kemudian akan melahirkan generasi yang berkualitas (Bali, 2019).

Sekolah yang menerapkan pembelajaran berbasis teknologi informasi dapat meningkatkan kompetensi siswa. Hal ini dapat dilihat di lembaga MI Miftahul Ulum yang menerapkan teknologi informasi dalam pembelajarannya. Berdasarkan interview penulis dari penuturan salah satu guru, siswa dalam lembaga tersebut semakin aktif, kreatif dan mandiri selama kegiatan pembelajaran berlangsung. Siswa lebih antusias menggunakan teknologi informasi dalam proses pembelajaran di kelas sehingga respon siswa dalam memahami materi lebih mudah dan lebih baik.

Guru sebagai orang yang terlibat langsung dalam proses pembelajaran ikut andil mengembangkan kurikulum yang ada sehingga tercipta kondisi dan suasana belajar yang kondusif dan menyenangkan. Ini menjadikan siswa merasa nyaman dan mudah dalam memahami pembelajaran. Oleh sebab itu, selain memiliki kompetensi yang harus dimiliki, guru perlu memahami penggunaan teknologi informasi dengan baik agar penerapan teknologi informasi dalam kelas terlaksana dengan baik dan tepat.

Undang-Undang RI No.14 Tahun 2005 tentang guru dan dosen pasal 1 memaparkan bahwa guru adalah pendidik profesional dengan tugas utama mendidik, mengajar, membimbing, mengarahkan, melatih, menilai, dan mengevaluasi peserta didik pada pendidikan usia dini jalur pendidikan formal, pendidikan dasar dan pendidikan menengah (Bali et al., 2019). Dengan demikian, penting bagi guru menguasai kompetensi-kompetensi yang harus dimiliki guru. Kompetensi tersebut adalah kompetensi pedagogik, kompetensi kepribadian, kompetensi sosial 
dan kompetensi profesional. Selain itu, guru juga perlu memiliki pemahaman yang dalam tentang pengajaran. Dua hal tersebut harus dimiliki guru agar tujuan pembelajaran tercapai dengan baik dan sesuai dengan tujuan pembelajaran.

With the application of information technology in learning can contribute to learning activities, namely the ongoing process of individual learning by fostering student independence in learning (Islam et al., 2018). Penggunaan teknologi informasi tersebut dapat berupa komputer, laptop, iphone, ipad dan sejenisnya. Siswa dapat berinteraksi langsung dengan sumber belajar dengan beragam variasi. Penggunaan teknologi informasi dalam kegiatan pembelajaran dapat membantu meningkatkan minat siswa dalam belajar. Dengan begitu, diperlukan guru sebagai fasilitator dan pengamat, artinya guru sebagai penyedia fasilitas dan pengamat perkembangan siswa selama pembelajaran berlangsung. Dalam pembelajaran ini berpusat pada siswa untuk mengembangkan keterampilan siswa dalam kegiatan pembelajaran.

\section{Penerapan Teknologi Informasi dalam Proses Pembelajaran}

Tugas guru sebagai fasilitator berkewajiban dapat menggunakan cara atau teknik penyampaian pesan kepada siswa dengan tepat. Dengan kerangka inilah guru bisa berharap tujuan pesan yang hendak disampaikannya kepada peserta didik dapat tercapai dengan maksimal. Bahkan, sukses tidaknya interaksi guru dengan siswa sangat dipengaruhi dan ditentukan oleh metode (Zaini, 2013).

Dalam proses belajar mengajar, hal utama yang harus diperhatikan oleh seorang guru dalam penggunaan media adalah berkaitan dengan analisis manfaat dari penggunaan media tersebut. Rustam (2011) memaparkan beberapa alasan yang harus diperhatikan dalam penggunaan media pembelajaran berkaitan dengan analisis manfaat yang akan diperoleh, yaitu: pertama, Pembelajaran akan lebih menarik perhatian peserta didik sehingga dapat menumbuhkan motivasi belajar. Kedua, Metode pembelajaran akan lebih bervariasi, tidak semata-mata komunikasi verbal melalui penuturan kata-kata oleh guru, sehingga peserta didik tidak bosan dan guru tidak kehabisan tenaga, apalagi bila guru harus mengajar untuk setiap jam pelajaran. Ketiga, Bahan pembelajaran akan lebih jelas maknanya sehingga dapat lebih dipahami oleh peserta didik dan memungkinkan peserta didik menguasai tujuan pembelajara lebih baik. Keempat, Peserta didik lebih banyak melakukan kegiatan belajar, sebab tidak hanya mendengarkan uraian guru, tetapi aktivitas lain seperti mengamati, melakukan, mendemonstrasikan dan lain-lain.

Teknologi informasi dapat dijadikan sebagai media pembelajaran alternatif lain selain media pembelajaran konvensional seperti buku ajar. Media ini dapat dijadikan sebagai pendukung bagi proses pembelajaran sehingga pembelajaran lebih efekstif dan efisien sehingga memudahkan proses pembelajaran dan pengajaran di kelas.

Teknologi yang digunakan untuk mengolah data, termasuk memproses, mendapatkan, menyusun, menyimpan, memanipulasi data dalam berbagai cara untuk menghasilkan informasi yang berkualitas, yaitu informasi yang relevan, akurat dan tepat waktu, yang digunakan untuk keperluan pribadi, pendidikan, bisnis, dan pemerintahan serta merupakan informasi yang strategis untuk pengambilan keputusan. Teknologi ini menggunakan seperangkat komputer untuk mengolah data, sistem jaringan untuk menghubungkan satu komputer dengan komputer yang lainnya sesuai dengan kebutuhan. Teknologi informasi bagi dunia pendidikan seharusnya berarti tersedianya saluran atau sarana yang dapat dipakai untuk menyiarkan program pendidikan. Pemanfaatan teknologi informasi dalam bidang pendidikan sudah merupakan kelaziman, yaitu untuk membantu mempermudah peserta dalam mendapatkan informasi kekinian mengenai materi pelajaran yang diterima (Syafruddin, 2019). 
Dengan adanya perkembangan zaman saat ini, perbaikan mutu pendidikan dilakukan terus menerus oleh pemerintah atau penyelenggara pendidikan. Salah satunya ialah pemerintah Kabupaten Lumajang yang menginstruksikan lembaga Madrasah Ibtidaiyah untuk menggunakan teknologi informasi dalam proses pembelajaran dengan tujuan hasil pembelajaran lebih maksimal. Selain itu, pengajaran penggunaan teknologi informasi sejak dasar dapat mengembangan pengetahuan siswa terhadap teknologi sehingga dapat dijadikan bekal untuk melanjutkan ke jenjang yang lebih tinggi.

Salah satu lembaga yang mengikuti kurikulum pemerintah tersebut adalah MI Miftahul Ulum yang berlaku pada siswa kelas 4, 5 dan 6 saja. Dalam penerapannya, penggunaan teknologi informasi tidak hanya berbasis komputer saja melainkan setiap siswa diharuskan memiliki alat teknologi informasi tersebut seperti laptop, iphone, ipad, tablet dan sejenisnya sebagai penunjang keberhasilan penggunaan teknologi informasi di kelas. Selain itu, pengaplikasian teknologi informasi tersebut bukan berbasis internet atau online, tetapi berbasis offline yakni guru memberikan soft file terkait materi pembelajaran kepada siswa, kemudian dipelajari sendiri oleh mereka. Baru kemudian terjadi diskusi antar siswa dari hasil belajar mereka.

Hal ini telah terjadi perubahan paradigma dari pendidikan konvesional menjadi pendidikan yang modern. Dalam pendidikan konvensional dikenal dengan istilah teacher centered dimana dalam proses proses pembelajarannya menggunakan metode klasikal, yaitu metode ceramah yang lebih memfokuskan pada guru saja yang menjelaskan materi dan siswa diam, hal ini dapat membuat siswa bosan terhadap pembelajaran. Dari teacher centered berkembang menjadi student centered dimana siswa aktif dalam pembelajaran, guru hanyalah fasilitator saja. Artinya penerapan student centered dalam pembelajaran akan melatih siswa untuk meningkatkan keterampilan dan kreativitas siswa.

Jadi, pada mulanya teknologi informasi hanya sebagai pemrosesan data. Namun dengan seiringnya perkembangan teknologi, maka teknologi informasi tidak hanya terbatas pada pemrosesan data, melainkan dapat digunakan dalam dunia pendidikan sebagai media pembelajaran guna meningkatkan mutu pendidikan.

\section{Kualitas Pembelajaran}

Hasil belajar dan kualitas siswa sangat dipengaruhi keberhasilan dalam proses pembelajaran. Pembelajaran yang efektif dan efesien juga dipengaruhi oleh kompetensi guru selama kegiatan pembelajaran. Dengan pembelajaran yang efektif dan efesien, tujuan pembelajaran dapat berjalan dengan baik.

Peningkatan kualitas salah satunya dilakukan dengan meningkatkan mutu pembelajaran. Peningkatan mutu pembelajaran dapat dicapai jika guru telah melakukan pembelajaran yang inovatif dengan menempatkan siswa sebagai pusat pembelajaran dan mereka dapat belajar bermakna (Gunantara et al., 2014). Dalam hal pembelajaran harus ditunjang dengan sebaikbaiknya dan selengkap-lengkapnya agar proses pembelajaran menjadi lancar, adapun hal- hal yang dapat menunjang proses pembelajaran tersebut diantaranya adalah :1. Pengetahuan 2. Kemampuan Membuat Perencanaan Pembelajaran 3. Kemampuan Menggunakan Media atau Alat Bantu Pelajaran 4. Kemampuan Menggunakan Metode 5. Kemampuan Mengelola Kelas 6. Kemampuan mengevaluasi (Azmi, 2014).

Memperhatikan fungsi guru yang sangat besar peranannya dalam proses pembelajaran, maka diperlukan metode dan taktik yang tepat dalam mengajar supaya siswa dapat memahami pembelajaran secara optimal. Guru sebagai praktisi pendidikan perlu melakukan inovasi dan kreatifitas dalam proses penerapan pembelajaran agar tujuan pembelajaran berhasil. Selain itu, 
media juga sangat diperlukan sebagai penyalur pesan dari guru kepada siswa agar pembelajaran lebih efektif.

Berdasarkan pembahasan di atas, telah disebutkan bahwa upaya yang dilakukan guru dalam proses pembelajaran dengan penerapan teknologi informasi di lembaga MI Miftahul Ulum yaitu menjadikan siswanya aktif dalam berinteraksi dengan sumber belajar atau media pembelajaran. Dengan penerapan teknologi informasi dalam pembelajaran, maka proses belajar mengajar terfokuskan pada siswa. Pembelajaran yang berpusat pada siswa memiliki manfaat yaitu mengembangkan keterampilan proses siswa seperti mengamati, mengklasifikasi, mengukur, mengamalkan dan menyimpulkan. Oleh sebab itu, penggunaan teknologi informasi dalam proses pembelajaran menjadikan siswa lebih mandiri, aktif dan kreatif selama kegiatan belajar mengajar berlangsung. Mereka akan melakukan diskusi dan tanya jawab baik dengan guru ataupun dengan teman.

Walaupun penggunaan teknologi informasi ini berpusat pada siswa, namun guru juga memiliki peranan penting sebagai fasilitator dan pengamat dalam pembelajaran. Berdasarkan hasil penelitian yang dilakukan, upaya yang dilakukan guru dalam pembelajaran ini yaitu: 1) mendorong siswa berinteraksi dengan sumber belajar atau media pembelajaran; 2) mendorong siswa untuk melakukan diskusi dengan teman-temannya; 3) mengajukan pertanyaan dari guru kepada siswa atau siswa kepada temannya; 4) memantau persepsi dan proses berfikir siswa; 5) memantau dan mengamati hasil pembelajaran

\section{Kesimpulan}

Berdasarkan hasil penelitian yang telah dilakukan, dapat disimpulkan bahwa penerapan teknologi informasi dalam proses pembelajaran di MI Miftahul Ulum dapat meningkatkan kualitas siswa. Siswa lebih aktif dan mandiri terhadap materi pembelajaran. Hal tersebut tidak akan menjadikan siswa gagap teknologi dalam menghadapi persaingan teknologi yang semakin canggih.

Dengan penerapan teknologi informasi dalam proses pembelajaran, maka kegiatan belajar mengajar lebih berpusat pada siswa. Guru hanyalah sebagai fasilitator dan pengamat terhadap kegiatan pembelajaran. Meskipun demikian, peranan guru tidak hanya sebagai fasilitator dan pengamat saja di kelas. Pembelajaran dengan penerapan teknologi informasi tidak akan berhasil jika tidak ada langkah atau upaya yang dilakukan guru untuk mendukung selama kegiatan berlangsung. Dengan demikian upaya guru sangat diperlukan dalam meningkatkan kualitas siswa guna menunjang keberhasilan di kelas.

\section{Daftar Pustaka}

Akakom, S. (n.d.). Pemanfaatan teknologi informasi dan komunikasi (tik) untuk meningkatkan kualitas pembelajaran.

Azmi, N. (2014). Pemanfaatan sumber belajar dalam meningkatkan kualitas pembelajaran.

Bali, M. M. E. I. (2019). Implementasi Media Pembelajaran Berbasis Teknologi Informasi dan Komunikasi dalam Distance Learning. Tarbiyatuna, 3(1), 28-38.

Bali, M. M. E. I., Zuhri, R. A. A., \& Agustini, F. (2019). RAGAM MEDIA PEMBELAJARAN: Desain Produksi dan Implementasinya di Madrasah Ibtidaiyah. In Pustaka Nurja. Pustaka Nurja. https://doi.org/9786025318894

Gunantara, G., Suarjana, M., \& Riastini, P. N. (2014). Penerapan Model Pembelajaran Problem Based Learning untuk Meningkatkan Kemampuan Pemecahan Masalah Matematika Siswa Kelas V. Jurnal Mimbar PGSD Universitas Pendidikan Ganesha Jurusan PGSD, 2(1), 1- 
10.

Islam, S., Baharun, H., Muali, C., Ghufron, M. I., Bali, M. M. E. I., Wijaya, M., \& Marzuki, I. (2018). To Boost Students' Motivation and Achievement through Blended Learning. Journal of Physics: Conference Series, 1114(1), 1-11. https://doi.org/10.1088/17426596/1114/1/012046

Khasanah, D. N., \& Pratiwi, A. E. (2018). Pengembangan Media Pembelajaran Berbasis Multimedia Interaktif di Sekolah Dasar. Prosiding Seminar Nasional KSDP Prodi S1 PGSD "Konstelasi Pendidikan Dan Kebudayaan Indonesia Di Era Globalisasi," 345-350.

Muali, C., Islam, S., Bali, M. M. E. I., Hefniy, H., Baharun, H., Mundiri, A., Jasri, M., \& Fauzi, A. (2018). Free Online Learning Based on Rich Internet Applications; The Experimentation of Critical Thinking about Student Learning Style. Journal of Physics: Conference Series, 1114(1), 1-6. https://doi.org/10.1088/1742-6596/1114/1/012024

Setiadi, A., Yuliatmojo, P., \& Nurhidayat, D. (2018). Pengembangan Aplikasi Android untuk Pembelajaran Pneumatik. Jurnal Pendidikan Vokasional Teknik Elektronika, I(1), 1-5.

Syafruddin. (2019). Pengembangan Digital Book Berbasis Android untuk Menstimulus Psikomotorik Siswa. Cyberspace: Jurnal Pendidikan Teknologi Informasi, 3(1), 8-18. https://doi.org/10.22373/cj.v3i1.4212

Training, T., Jl, I. P., Km, R. N., \& Padangsidimpuan, S. (1984). PENGEMBANGAN PENDIDIKAN ISLAM DENGAN IMPLIKASI TEKNOLOGI PENDIDIKAN Nasruddin Hasibuan. 189-206. 